\title{
Collaborative Paragraph Writing in Students' Writing Skill
}

\author{
Syamsuarni $^{1 *}$, Jufrizal ${ }^{2}$, and Yenni Rozimela ${ }^{3}$ \\ ${ }^{123}$ English Department, FBS Universitas Negeri Padang, Padang, Sumatra Barat 25131, Indonesia \\ *Corresponding author. Email: syamsuarnibakar@gmail.com
}

\begin{abstract}
This study explores the effect of collaborative writing technique to students' writing skill in writing recount paragraph. This experimental research was conducted in 4 weeks (8 meetings). 33 students participated in experimental group, whereas the other 33 students was in a control group. Writing test was conducted. The findings showed that the technique gave a significant effect to students' writing skills. It can be suggested that English teachers need to apply this technique as an alternative technique in teaching writing in English, especially in recount paragraph.
\end{abstract}

Keywords: collaborative paragraph writing, writing skill

\section{INTRODUCTION}

Based on the curriculum 2013 of English for Senior High School (Kemendikbud, revised edition 2014), the scope of learning English at Senior High school is that students are able to understand and produce any kind of functional texts. It means that they should have ability to express their ideas, feeling, and understanding for any kinds of text. Some text types that should be mastered by the students at Senior High Schools are descriptive, procedure, recount, narrative, report, news item, analytical exposition, hortatory exposition, spoof, explanation, discussion, and review text. Each text has different goals, generic structures and lexico grammatical features.

From several texts above, recount text is one of text types learnt by the grade $\mathrm{X}$ students of Senior High School in the first semester. The students are expected to be able to understand and write the recount text as it is stated in curriculum 2013. Therefore, both teacher and students need an extra effort to achieve the goal. Ideally, the students need to practice and develop their writing skill since it is a productive skill that is important for them in the process of acquiring the language and knowledge. In addition, teachers are also required to find and apply appropriate techniques in teaching writing. The teachers have to consider to use technique that accommodates both writing skill and writing technique.

Dealing with conventional technique, free writing is the common technique used in teaching writing. The activities of this technique are started with brainstorming, introducing the topic, asking students to discuss the topic in pairs, leading students to discuss what they want to write later, asking students to take a note of what they are going to write, asking students to pay attention to spelling, punctuation, transitional markers and other writing mechanic, and asking students to peer correct their writing. This technique motivates them to be more active in writing paragraphs in English. Although the free writing technique is believed as one of effective techniques in teaching writing, it is found that the technique does not always become the best technique to use all the time in teaching writing.

One of the various teaching techniques that can be applied in teaching writing is collaborative paragraph writing technique. This technique helps both teachers and students to create the classroom writing activities enjoyable. Students are expected to be able to develop their ideas in writing recount paragraphs. It is assumed that applying the collaborative paragraph writing technique is regarded as an effective technique to motivate the students to write in English. However, there is no single teaching technique or strategy could improve students' writing skill, but there are some rational reasons why using collaborative paragraph writing technique.

Collaborative paragraph writing technique is applied in the whole writing stages (brainstorming, classifying ideas and organizing ideas). It means the technique is useful to lead and guide the students before, during and after writing process. By doing so, it is hoped that the students' writing skill will be better.

Furthermore, collaborative paragraph writing technique emphasizes on student-centered learning rather than teacher-centered learning. So, the writing class will be more enjoyable, lively and meaningful. Finally, collaborative paragraph writing technique is effective to encourage and motivate students with different abilities to be more active and interested in writing activities. 
Several studies had been conducted dealing with collaborative paragraph writing technique: Storch [1], Hendry [2], Suwantarathip [3], Aminloo [4], Wahyuni [5] and Rozimela, Anwar, and Anggraini [6] . They found that this technique afforded students the opportunity to pool ideas and provide each other with feedback. It can also activate students' background knowledge of the topics assigned to them and improve their paragraph writing skill. In addition, students reported that they had positive attitudes toward collaborative writing activity and high collaboration in their groups.

\section{METHOD}

The quasi experimental research was conducted in this study because the researcher manipulated one independent variable then controled one dependent variable and observed the effect of independent variable. Gay, Milis and Airasian [7] explain that "post test scores of the experimental and control group are compared to determine the effectiveness of collaborative paragraph writing technique after giving the treatment". Creswell: 2009 has proposed that the suitable research design is quasi experimental design in the post-test only control group design. It can be drawn as follows:

$$
\begin{aligned}
& \text { G1: --- X ---- O2 } \text { G2: -------- O2 } \\
& \text { G1 }=\text { Experimental Group } \\
& \text { G2 }=\text { Control Group } \\
& \mathrm{X}=\text { Treatment } \\
& \mathrm{O} 2=\text { Post Test }
\end{aligned}
$$

The population of the research was all the $10^{\text {th }}$ grade of SMAN 1 Batang Anai (2016/2017). There were 196 students. Each class had approximately 33 students. From the six classes, two classes were chosen as sample. In selecting the sample, researcher used cluster sampling technique. "Cluster sampling is sampling in which groups, not individually, are randomly selected" [7]. Here, the researcher selected two groups randomly: experimental group and control group.

Two classes were chosen as sample out of the six classes as the population of this research. The others were not assigned in this research. In order to find two groups or classes, the researcher used the result of students' English mid semester test which had no significant difference from one which was taken as sample of the research conducted. The students' mark was then analyzed by finding the mean scores of the mark. A coin was tossed to see which of the two classes was an experimental class and which one was a control one. Furthermore, presentation of collaborative paragraph writing was applied in the experimental group while a control group received conventional technique. In addition, identical materials and the same amount of time were given in two groups, except for the technique.

To determine the two selected classes were chosen as sample in this research, the researcher did two steps. The first thing done by the researcher was testing the normality and homogeneity of the population to know whether the sample was normally distributed and homogeneous. In this case, the researcher applied Lilifors Testing for normality testing and Bartlet formula for homogeneity testing. Next, cluster sampling was also applied since the samples had been grouped into their already existing classes.

Researcher also flipped the coin to determine which of the two selected classes acted as an experimental class and a control class. The first class was an experimental class, whereas the second class appeared to be a control class. So, there were two kinds of variables used in this research. The two techniques, collaborative paragraph writing technique and conventional technique, acted as independent variables. Meanwhile, the students' writing test played role as a dependent variable.

\section{RESULT AND DISCUSSION}

\section{A. RESULT}

All the data needed in this research were collected from the writing test as posttest. The test was used to measure students' skill in writing recount paragraph. The data from the writing test were gathered after the treatment. Control and experimental class were given different treatments. In the experimental class, students were taught using collaborative paragraph writing technique, while conventional technique was employed in the control group. The students who were taught by using collaborative paragraph writing technique were 33 students. In this research, the researcher gave 100 for the maximum score for each student. The highest score of the writing test was 93 , and the lowest score was 51 . The total score of the experimental class was 2333 with the mean score 70.7. In control class, there were also 33 students with the maximum score 100 for each student. The highest score of writing test was 81, and the lowest score was 53 . The total score of students' writing skill in control class was 2111 with the mean score 63.9.

Table 1. The Summary of Students' Writing Test Test of Experimental and Control Class

\begin{tabular}{|l|c|c|}
\hline Statistics & $\begin{array}{c}\text { Writing } \\
\text { Experimental }\end{array}$ & $\begin{array}{c}\text { Writing } \\
\text { Control }\end{array}$ \\
\hline Sum & 2333 & 2111 \\
\hline Mean & 70.69697 & 63.9 \\
\hline Min & 51 & 53 \\
\hline Max & 93 & 81 \\
\hline
\end{tabular}


In this research, hypothesis testing used t-test. The result of writing skill t-test for both of experimental and control class can be seen at table 2 .

Table 2. Summary of t-test students' writing skill of experimental and control class

\begin{tabular}{|c|c|c|}
\hline t $_{\text {observed }}$ & $t_{\text {table }}$ & Note \\
\hline 26.6 & 1.671 & 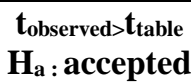 \\
\hline
\end{tabular}

Based on the table above, it can be concluded that $t_{\text {observed }}>t_{\text {table. It means that }} H_{o}$ is rejected and $H_{a}$ is accepted.

\section{B. Discussion}

The result of the first hypothesis testing shows that Collaborative Paragraph Writing technique is meaningful to be implemented to the students' writing skill, especially writing recount paragraph. The activities done in collaborative paragraph writing technique make the students got better achievement in writing recount paragraph because the students were actively participating in the groups by sharing their ideas toward the paragraph they are writing. As stated by [9] Serbessa collaborative paragraph writing is two or more people sharing responsibility for producing a single document through mutual interactions, shared expertise, and joint decision-making throughout the writing process. Through discussion, change of idea, the students get more portions to directly involve in the process of studying and students are responsible for the smoothes of studying process. Meanwhile, the students in the control class did not get better achievement because the teachers dominated in the teaching and learning process. The students tended to be passive during teaching and learning process. They did not discuss with their friend about the difficulties that happened during writing process. It made them got low achievement in writing.

Because of the students' activities in collaborative paragraph writing, the students got high achievement in writing recount paragraph, while the students that were taught by conventional technique did not get better result. Multiple inputs from each member also produce a good writing and reduce the grammatical errors. In contrast, students in control class that was taught by conventional technique make their writing individually. It makes the students find difficulties in doing their writing because it was hard for them to develop their ideas.

This is supported by Aminloo [4] who says that Collaborative Paragraph Writing technique is a technique which gathers ideas that is a kind of free association about one concept deals with any interrelated information. Collaborative Paragraph Writing is the technique which can improve students' skill in writing since it digs information from the collaborative construction which is finally arranged into a well-organized paragraph. Moreover, Wahyuni [5] finds out that Collaborative Paragraph Writing is an effective technique in language learning which is preferred by the students because it is interesting, fun, and encourages their creativity with its collaborative construction in creating new vocabulary and forming new sentence pattern. In line with this, Harmer [8] states that Collaborative Paragraph Writing technique is a visual organizer which will help the students to organize ideas into a well written work. It is a useful device for teachers especially English teachers in teaching their students on how to write. Last but not least, [11] Hendry also claims that Collaborative Paragraph Writing is a technique that is applicable in three phases of writing process. It is not only beneficial in pre-writing phase, but also in whilst-writing and post-writing activity.

\section{CONCLUSION}

Based on the results of data analysis, it can be concluded that the students who were taught by using Collaborative Paragraph Writing technique got better writing score of recount paragraph than those who were taught by using conventional technique. The reason of this situation is that Collaborative Paragraph Writing technique provides enough opportunities for the students to practice their writing through interesting activities in group. The activities also give equal opportunities to each student to practice their writing skill individually and minimize the gap between the dominant and passive students.

\section{ACKNOWLEDGMENT}

Alhamdulillah, praise to Allah swt who has given her health and blessing in finishing this research entitled "The Effect of Collaborative Paragraph Writing Technique on Students' Writing Skill at Grade X of SMAN 1 Batang Anai”. Then, the researcher would like to express her sincere gratitude to those who have given their contribution in completing this research. Her deepest gratitude goes to Mr. Jufrizal and Ms. Yenni Rozimela as her advisors who have given valuable advice, meaningful contributions, guidance and assisstance in accomplishing this research. It is her pleasure to work under their guidance. The researcher would also like to express her deep thanks to Mr. Hamzah and Mr. Refnaldi as the contributors who have given their contribution and suggestions for the improvement of this research and Ms. Ratmanida who has also kindly and friendly assissted and guided her in constructing and validating the post test as the instrument of this research. 


\section{REFERENCES}

[1] Storch, Neomy. 2005. Collaborative writing: Product, process, and students' reflections. Journal of Second Language Writing 14 (2005). The University of Melbourne, Parkville, Victoria 3010. Australia

[2] Hendry, John. 2009. Improving Students' Paragraph Writing Through Collaborative Paragraph Construction At Grade X2 of SMAN 1 Lubuk Sikaping. UNP Padang: Thesis

[3] Suwantarathip. 2013. The Effect of Collaborative Writing Activity Using Google Docs on Students' Writing Abilities. Language Institute, Bangkok University, Thailand.

[4] Aminloo, Masoumeh Shiri. 2013. The Effect of Collaborative Writing on EFL Learners Writing Ability at Elementary Level. Journal of Language Teaching and Research, Vol.4. Islamic Azad University, Damavand. Iran

[5] Wahyuni, Irna. 2014. The Effect of Collaborative Writing and Reading Habit toward The Students' Writing of Recount Text at the Grade Eight of MTsN Kamang. UNP Padang: Thesis

[6] Rozimela, Y., Anwar D., and Anggraini, R. (2020). The Effect of Collaborative Writing on EFL Learners' Writing Skills and Their Perception of the Strategy. Journal of Language Teaching and Research. 11 (2): 335-341.

[7] Gay, L.R. and Airasian, Peter. 2000. Educational Research: Competencies for Analysis and Application. (6 ${ }^{\text {th }}$ ed). New Jersey: Prentice-Hall Inc.

[8] Harmer, Jeremy. 2000. Teacher Knowledge. Core Concepts in English Langugae Teaching. Harlow: Pearson Education Limited.

[9] Serbessa, Derebssa. 2006. "Tension Between Traditional and Modern Teaching Learning Approaches in Ethiopian Primary School". CICE Horishima University Journal of International Cooperation Education, Vol 9 No. 1 pp. 123-140.

[10] Banerjee, R. (2000). The benefits of collaborative learning. Retrieved October 8, 2011, from http://www.brighthub.com/education/k12/articles/70619.aspx

[11] Creswell, John W. 2009. Research Design; Qualitative, Quantitative, and Mixed Method Approaches. California: SAGE Publications, Inc. 